\title{
PENGUASAAN KOMPETENSI PEDAGOGIK GURU PENGARUHNYA TERHADAP KOMPETENSI SIKAP KEWIRAUSAHAAN SISWA (STUDI KASUS PADA PEMBELAJARAN MATA PELAJARAN KEWIRAUSAHAAN)
}

\author{
Endang Supardi; Janah Sojanah; Adman
}

Email: endang-supardi@upi.edu; janahsojanah@upi.edu, adman@upi.edu

\begin{abstract}
ABSTRAK
Hasil penelitian ini dilakukan pada siswa SMK Negeri 11 Bandung. Yang mana tujuannya untuk mengetahui seberapa besar pengaruh penguasaan kompetensi pedagogik guru pengaruhnya terhadap sikap kewirausahaan siswa . Masalah yang menjadi kajian dari penelitian ini adalah mengenai rendahnya sikap kewirausahaan siswa. Inti kajiannya difokuskan pada salah satu faktor yang mempengaruhi sikap kewirausahaan siswa yaitu penguasaan kompetensi pedagogik guru. Penelitian ini terdiri dari dua variabel yaitu Penguasaan Kompetensi Pedagogik Guru (X) dan Sikap Kewirausahaan Siswa (Y). Penguasaan Kompetensi Pedagogik diukur melalui tiga indikator, yaitu kompetensi menyusun rencana pembelajaran, kompetensi melaksanakan proses belajar mengajar, kompetensi melaksanakan penilaian proses belajar mengajar. Sikap Kewirausahaan diukur melalui enam indikator, yaitu kepercayaan diri, berorientasi pada tugas dan hasil, pengambilan resiko, kepemimpinan, keorisinilan, dan berorientasi ke masa depan.

Penelitian ini menggunakan metode deskriptif, teknik pengumpulan data menggunakan angket. Analisis data menggunakan analisis regresi. Anggota sampel sebanyak 75 orang. Secara garis besar, keadaan Penguasaan Kompetensi Pedagogik Guru di SMK Negeri 11 Bandung termasuk kategori baik. Artinya Penguasaan Kompetensi Pedagogik telah dimiliki Guru secara rata,efektif dan efisien. Sikap Kewirausahaan di SMK Negeri 11 Bandung termasuk kategori tinggi. Artinya kompetensi pedagogic yang telah dicapai guru sudah baik, hal tersebut perlu dipertahankan dan diupayakan terus ditingkatkan.

Hipotesis yang penulis ajukan dapat diterima yaitu adanya Penguasaan Kompetensi Pedagogik Guru pengaruhnya terhadap peningkatan Sikap Kewirausahaan Siswa.
\end{abstract}

Kata Kunci : Penguasaan Kompetensi Pedagogik, dan Sikap Kewirausahaan Siswa 


\section{Latar Belakang Masalah}

Sebagai negara berkembang Indonesia, saat ini sedang berusaha melaksanakan pembangunan segala bidang. Bidang pendidikan merupakan prioritas utama, hal itu sesuai dengan amanat UUD 1945 yaitu terwujudnya masyarakat yang adil dan makmur, karena pendidikan memegang peranan penting untuk menghasilkan sumber daya manusia yang maju, mandiri, produktif, berkualitas, dan berdaya guna. Karena pendidikan merupakan sebuah tolok ukur bagi sebuah negara, jika pendidikan di negara tersebut bagus, maka dapat dipastikan kualitas negara itupun menjadi bagus juga.

Sumber daya manusia ini tidak lain ditentukan oleh hasil produktivitas lembagalembaga penyelenggara pendidikan, yang terdiri atas jalur sekolah dan luar sekolah, dan secara spesifik merupakan hasil proses pembelajaran di kelas. Karena inti dari kegiatan sekolah atau kelas adalah proses belajar mengajar (PBM).

Mutu pendidikan dan keberhasilan dalam proses pembelajaran ditandai dengan prestasi pada siswa dan perubahan perilaku sebagai ukurannya. Hal ini berarti berhasil tidaknya proses bergantung pada tinggi rendahnya prestasi belajar siswa. Oleh karena itu, setelah mengalami proses pendidikan dalam jangka waktu tertentu semua peserta didik diharapkan menunjukkan perilaku positif sebagai prestasi belajar. Sehingga penyelenggaraan proses pendidikan harus dapat memenuhi kriteria keberhasilan yang optimal. Indikator yang dapat dijadikan tolak ukur keberhasilan proses pendidikan menurut Uzer Usman (dalam Rosalina, 2007:8), adalah :

a. Daya serap terhadap mata pelajaran yang diajarkan mencapai prestasi tinggi baik secara individu maupun kelompok.

b. Perilaku yang digariskan dalam tujuan pengajaran instruktusional khusus telah dicapai siswa baik secara individu maupun kelompok.

Banyak siswa yang telah melakukan pembelajaran sulit untuk mengaplikasikan dalam kehidupan sehari-hari. Mulai dari sikap, keterampilan dan pemahaman secara kreatif dan inovatif. Mereka mengaplikasikannya kurang memahami pelajaran dan tidak tahu untuk memulai perubahannya dari mana. Siswa hanya terpaku pada materi, tes, dan nilai yang ingin mereka dapatkan. Padahal yang dituntut dalam sebuah pembelajaran adalah siswa tahu, mengerti, memahami dan menerapkan dalam kehidupannya, seperti perubahan pada sikap.

\section{Tabel 1}

\section{Nilai Siswa Praktek Usaha Kecil} (Siswa Aktif)

\begin{tabular}{|c|c|c|}
\hline Kelas & Jumlah Siswa & Rata-rata Nilai \\
\hline XI AP 1 & 35 siswa & 72,3 \\
\hline XI AP 2 & 35 siswa & 72,8 \\
\hline XI AP 3 & 33 siswa & 72,6 \\
\hline XI AP 4 & 33 siswa & 72,3 \\
\hline Jumlah & 136 siswa & $\mathbf{7 2 , 5}$ \\
\hline
\end{tabular}

Sumber: Guru Mata Pelajaran Kewirausahaan Kelas XI Administrasi Perkantoran Data jumlah diambil data dari empat kelas, yaitu XI AP 1, XI AP 2, XI AP 3, dan

Manajerial, Vol. 2 No. 2 Januari 2017, Hal - 47

http://ejournal.upi.edu/index.php/manajerial/

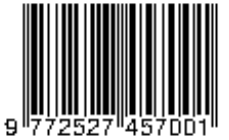


AP 4, yang melakukan praktek pada Semester Tiga Tahun Pelajaran 2015/2016. Kegiatan dilakukan pada jam mata pelajaran Kewirausahaan, yaitu dua jam normal. Praktek yang mereka jalani adalah praktek usaha kecil. Guru memberikan tugas kepada siswa secara kelompok yang beranggotakan lima sampai enam orang untuk membuat suatu usaha makanan kecil yang mereka kelola sendiri mulai dari modal awal, pembelian bahan-bahan, peralatan yang dibutuhkan, pembuatan makanan, sampai kepada penjualan di lingkungan sekolah. Makanan yang dijual kebanyakan berupa gorengan, cemilan, kue-kue, puding, keripik, dll. Rata-rata modal awal yang mereka keluarkan berkisar Rp. 20.000 - Rp. 25.000 per kelompok, dan mereka mendapatkan laba rata-rata Rp. 5.000 - Rp. 7. 000 per kelompok. Siswa per orang nya hanya mendapat Rp. 1.000 dari penjualan tersebut.

Kiat yang bisa digunakan untuk dapat membantu mengembangkan sikap kreatif adalah sebagai berikut :

1. Tentukan Apa Yang Anda Inginkan, seperti mengambil waktu untuk memahami permasalahan sebelum mencoba memecahkannya, kumpulkan seluruh fakta dalam benak, dan cobalah identifikasi fakta- fakta yang paling penting.

2. Rilek, beberapa teknik rileksasi di antaranya termasuk menjernihkan pikiran, mendengarkan alunan suara yang indah, meditasi, mendengarkan humor dari orang lain, berhenti sejenak memikirkan segala permasalahan untuk kembali kemudian.

3. Latihlah Otak Anda, aktivitas yang termasuk di dalamnya adalah keluarkanlah semua gagasan tanpa harus menyebutkan pemecahannya terlebih dahulu, latihan berkonsentrasi pada isu tunggal, cobalah memikirkan penyelesaian-penyelesaian unik terhadap masalah masalah pribadi atau masalah-masalah kerja Anda dan latihlah cara menerima kurangnya kendali.

Secara garis besar terdapat dua faktor utama yang sangat menentukan dalam pencapaian prestasi belajar dan perubahan perilaku, yaitu faktor internal dan eksternal. Faktor internal secara lain yaitu minat, bakat, motivasi, kebiasaan belajar, kondisi fisik, dan sebagainya.

Dari uraian permasalahan di atas akan penulis batasi dalam bentuk identifikasi masalah yang dapat dirumuskan sebagai berikut :

1. Bagaimana gambaran kompetensi pedagogik guru di SMK Negeri 11 Bandung ?

2. Bagaimana gambaran kompetensi sikap kewirausahaan siswa di SMK Negeri 11 Bandung?

3. Adakah pengaruh penguasaan kompetensi pedagogik guru pada kompetensi sikap kewirausahaan siswa pada mata pelajaran kewirausahaan di SMK Negeri 11 Bandung ?

Tujuan yang ingin dicapai dalam penelitian ini ingin mengetahui :

1. Sajauhmana Penguasaan kompetensi pedagogik guru dalam mata pelajaran kewirausahaan?

2. Sejauhmana Kompetensi sikap kewirausahaan siswa dalam mempelajari mata pelajaran kewirausahaan?

3. Adakah pengaruh Penguasaaan kompetensi pedagogik guru terhadap Kompetensi sikap 
kewirausahaan siswa pada mata pelajaran kewirausahaan?

\section{Tinjauan Pustaka}

Menurut Charles (1994) mengemukakan bahwa competency as rational performance which satisfactorily meets the objective for a desired condition (kompetensi merupakan perilaku yang rasional untuk mencapai tujuan yang dipersyaratkan sesuai dengan kondisi yang diharapkan).

Sedangkan dalam Undang-Undang Republik Indonesia Nomor 14 Tahun 2005 tentang Guru dan Dosen, dijelaskan bahwa : kompetensi adalah seperangkat pengetahuan, keteampilan, dan perilaku yang harus dimiliki, dihayati, dan dikuasai oleh guru atau dosen dalam menjalankan tugas keprofesionalan".

Berdasarkan pendapat para ahli diatas dapat disimpulkan bahwa kompetensi guru adalah kemampuan dasar yang harus dimiliki oleh guru dalam melaksanakan tugasnya sebagai pendidik, sehingga tujuan dari pembelajaran sesuai dengan yang diharapkan bisa tercapai.

\section{Kompetensi Pedagogik Guru}

Dimensi kompetensi pedagogik merupakan kompetensi yang harus dimiliki oleh guru dalam mengelola pembelajaran peserta didik, perancangan dari pelaksanaan pembelajaran, evaluasi hasil belajar dan pengembangan peserta didik untuk mengaktualisasikan berbagai potensi yang dimilikinya.

\section{Konsep Sikap Kewirausahaan Siswa}

Sikap merupakan kesiapan merespon dan sebagai suatu penghayatan terhadap suatu objek serta merupakan suatu arah membimbing perilaku individu untuk bertindak terhadap objek tersebut. Sikap dapat berupa hasil bawaan dan bisa pula sebagai hasil belajar, sikap terkait dengan keyakinan, kebiasaan dan pendapat. Namun itu menunjukkan adanya pengaruh yang sama terhadap pembentukkan sikap individu.

Suryana (2003:8) juga mengatakan bahwa kewirausahaan merupakan suatu kemampuan dalam menciptakan nilai tambah di pasar bisnis melalui proses pengelolaan sumber daya dengan cara-cara baru dan berbeda melalui :

1. Pengembangan teknologi baru

2. Penemuan pengetahuan ilmiah baru

3. Perbaikan produk barang dan jasa yang ada

4. Penemuan cara-cara baru untuk menghasilkan barang lebih banyak dengan sumber daya yang lebih efisien.

Sehingga dapat disimpulkan bahwa kewirausahaan itu ialah kemampuan menggerakkan orang-orang dan berbagai sumber daya untuk berkreasi, mengembangkan, dan menerapkan solusi terhadap berbagai masalah agar dapat memenuhi kebutuhan manusia. 


\section{Kerangka Pemikiran}

Dasar pemikiran yang melandasi penelitian ini adalah untuk mengkaji masalah sikap kewirausahaan siswa ditinjau dari kompetensi pedagogik guru. Asumsi dasarnya bahwa kompetensi pedagogik guru memiliki pengaruh terhadap sikap kewirausahaan siswa.

Pendekatan yang digunakan untuk memecahkan masalah penelitian ini menggunakan pendekatan dari teori belajar, khususnya teori behaviorisme. B.F. Skinner (1904-1990) mengungkapkan bahwa konsep dasar teori belajar behaviorisme merupakan pengulangan dan pelatihan supaya perilaku yang diinginkan dapat menjadi kebiasaan. Teorinya berhadapan dengan perubahan-perubahan perilaku yang bisa diteliti,, melalui stimulus-respon (reward). Kerangka konseptual teori behaviorisme dapat digambarkan sebagai berikut:

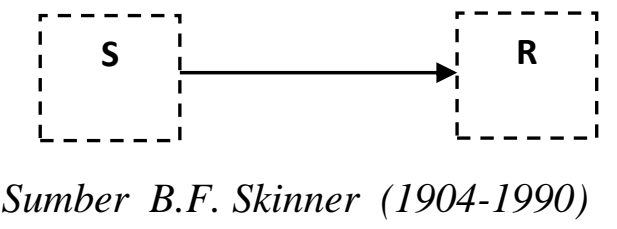

\section{Gambar 1}

\section{Kerangka Konseptual Teori Behaviorisme}

Kerangka di atas menunjukkan bahwa stimulus (S) mewakili segala sesuatu yang berada dalam lingkungan, dan respon (R) mewakili segala sikap sebagaimana dapat diamati, dihayati dan diukur. Stimulus (S) dapat mempengaruhi terjadinya respon (R) dengan adanya reward atau penghargaan atas sikap yang didapatkan. Respon (R) atau sikap yang diinginkan akan mendapatkan penguatan positif dan sikap yang kurang sesuai mendapat penghargaan negatif. Evaluasi atau penilaian didasari atas respon (R) atau sikap yang tampak.

Upaya perbaikan sikap kiranya harus dibangun suatu landasan kuat untuk meningkatkan kualitas kinerja guru. Geoffrey G. Meredith dalam Suryana (2006:24) yang mengemukakan bahwa ciri-ciri utama kewirausahaan dapat dilihat dari watak dan perilakunya, yaitu :

1. Kepercayaan diri

2. Berorientasi pada tugas dan hasil

3. Pengambilan resiko

4. Kepemimpinan

5. Keorisinilan

6. Berorientasi ke masa depan

Salah satu faktor keberhasilan dalam penyampaian materi kewirausahaan ditentukan oleh instruktur atau pendidik (guru). Kualitas dari seorang guru sangat berpengaruh terhadap penyampaian materi dan pola pikir peserta didiknya. Pendidik (guru) merupakan penghantar dari yang diajarkan (materi) terhadap yang diajarnya (murid). 

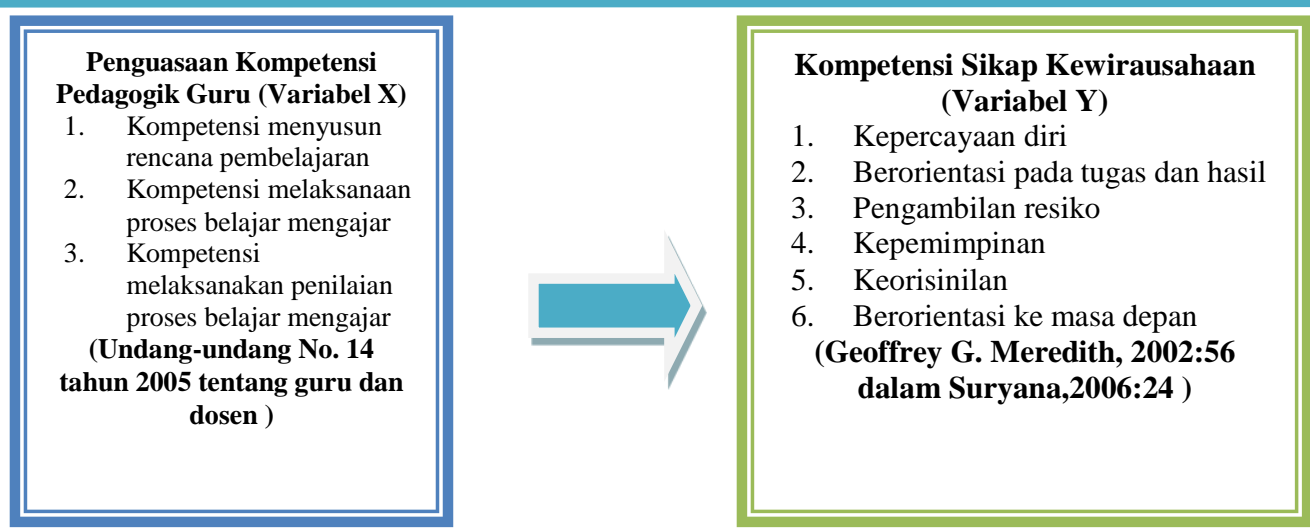

Gambar 2

Skema Variabel Penelitian

Model Pengaruh Penguasaan Kompetensi Pedagogik terhadap Kompetensi Sikap Kewirausahaan Siswa

Berdasarkan uraian di atas, diduga terdapat pengaruh yang besar antara kompetensi pedagogik guru terhadap sikap kewirausahaan siswa. Dengan kata lain semakin tinggi kompetensi pedagogik guru, maka akan semakin besar pula pengaruhnya terhadap sikap kewirausahaan siswa.

\section{Hipotesis}

Berdasarkan kerangka berpikir yang telah dikemukakan di atas, dapat dirumuskan hipotesis dalam penelitian ini, sebagai berikut : "penguasaan kompetensi pedagogik guru berpengaruh terhadap kompetensi sikap kewirausahaan siswa pada mata pelajaran kewirausahaan".

\section{Metode Penelitian}

Metode penelitian harus ditetapkan di dalam kegiatan penelitian sebagai pegangan yang jelas dan memandu peneliti mengenai bagaimana penelitian dilakukan sehingga penelitian dapat dilakukan secara efektif dan efisien sesuai dengan tujuan penelitian. Pemilihan dan penentuan metode yang dipergunakan dalam suatu penelitian sangat berguna bagi peneliti karena dengan pemilihan dan penentuan metode yang tepat dapat membantu dalam mencapai tujuan penelitian.

Sampel yang akan diambil merupakan wakil atau sebagian dari populasi yang diteliti. Sampel dalam penelitian ini adalah siswa Jurusan Administrasi Perkantoran SMK Negeri 11 Bandung tahun ajaran 2015/2016 sebanyak 136 orang.

Berdasarkan pernyataan tersebut, karena sampel penelitian ini diambil secara acak (random sampling) dengan sampel lebih dari 100 yaitu 136 orang. Maka penulis menetapkan jumlah sample penelitian ini adalah $55 \%$ x 136 orang $=75$ orang.

\section{Hasil dan Pembahasan}

Untuk mengetahui gambaran empirik tentang bagaimana persepsi siswa terhadap 
Kompetensi pedagogik guru (Variabel X) dan Sikap kewirausahaan siswa (Variabel Y) di SMK Negeri 11 Bandung terlebih dahulu harus dibuatkan suatu ukuran standar sebagai pembanding.

Ukuran standar pembanding tersebut dapat dibuat dengan memanfaatkan skor kriterium yang dibagi menjadi lima tingkatan, yaitu daerah sangat tinggi, tinggi, sedang, rendah dan sangat rendah berikut penjabaran skor kriterium dari masing-masing variabel:

Penelitian mengenai kompetensi pedagogik guru diperoleh dari penyebaran angket yang kemudian dihitung skor rata-rata terhadap skor responden. Keseluruhan indikator analisis pekerjaan dituangkan dalam 15 item pernyataan angket berdasarkan perhitungan dari 75 siswa sebagai responden.

Indikator yang digunakan dalam variabel kompetensi pedagogik guru diukur oleh kompetensi menyusun rencana pembelajaran (RPP), kompetensi melaksanakan proses belajar mengajar, kompetensi melaksanakan penilaian proses belajar mengajar

Indikator yang digunakan dalam variabel kompetensi pedagogik guru diukur oleh:

1) Kompetensi menyusun rencana pembelajaran;

2) Kompetensi melaksanakan proses belajar mengajar;

3) Kompetensi melaksanakan penilaian proses belajar mengajar.

Permasalahan yang ingin dijawab pada penelitian ini adalah "Adakah pengaruh Kompetensi Pedagogik Guru Terhadap Sikap Kewirausahaan Siswa.”

Berikutnya hasil analisis data perhitungan (tergambar pada lampiran) dapat diperoleh kesimpulan bahwa Kompetensi Pedagogik mempunyai pengaruh yang besar terhadap Sikap Kewirausahaan Siswa. Hal ini jelas sekali dari perolehan perhitungan uji signifikansi, menunjukkan bahwa $F_{\text {hitung }} \geq F_{\text {tabel }}$ atau $128.090 \geq 3963$, dan dengan koefisien determinasi (KD) menunjukkan bahwa kompetensi pedagogik mempengaruhi sikapkewirausahaan siswa sebesar $39.03 \%$ pada posisi (sedang) dan sisanya ditentukan oleh variabel lain yang memerlukan penelitian lebih lanjut.

Secara empirik dari hasil penelitian ini menindikasikan bahwa semakin tinggi kompetensi pedagogik yang dimiliki guru, akan diikuti oleh semakin tingginya sikap kewirausahaan siswa. Hal ini dapat diterangkan oleh persamaan regresi $\hat{Y}=1.54+1.63 X$. Dengan persamaan regresi tersebut dapat diinterprestasikan bahwa jika kompetensi pedagogik guru (X) sikap kewirausahaan siswa (Y) diukur dengan instrumen yang dikembangkan dalam penelitian ini, maka setiap perubahan skor kompetensi pedagogik sebesar satu satuan dapat diestimasikan skor tingkat sikap kewirausahaan siswa akan berubah sebesar $0,393 \mathrm{X}$ satuan pada arah yang sama.

Dari hasil temuan empirik di atas yang menunjukkan adanya pengaruh yang signifikan antara kompetensi pedagogik dengan sikap kewirausahaan siswa hasil penelitian ini memberikan beberapa informasi, Pertama kompetensi pedagogik memberikan pengaruh yang berarti terhadap peningkatan sikap kewirausahaan siswa. Kedua, salah satu cara untuk meningkatkan sikap kewirausahaan siswa adalah dengan kompetensi pedagogik. Ketiga, temuan ini memberikan penegasan terhadap teori-teori sikap kewirausahaan siswa yang menyebutkan bahwa sikap kewirausahaan siswa dipengaruhi

Manajerial, Vol. 2 No. 2 Januari 2017, Hal - 52

http://ejournal.upi.edu/index.php/manajerial/

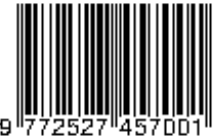


oleh berbagai faktor yang salah satunya adalah kompetensi pedagogik. Keempat, temuan ini memberikan penegasan terhadap teori-teori yang menyebutkan bahwa sikap yang dimiliki siswa semakin tinggi hal tersebut tentunya berdampak pada peningkatan kemampuan penguasaan atau kompetensi sikap kewirausahaan siswa. Sehingga diharapkan semakin tinggi sikap yang dimiliki siswa maka semakin tinggi juga sikap atau jiwa kewirausahaan siswanya.

\section{Kesimpulan dan Saran}

Adapun kesimpulan yang dapat penulis kemukakan adalah sebagai berikut : Secara umum gambaran Kompetensi Pedagogik Guru yang dijalankan dan dilaksanakan di SMK Negeri 11 Bandung yang ditunjukkan oleh penelitian bahwa Kompetensi Pedagogik pada guru sudah hampir sama dan rata sehingga termasuk pada kategori baik. Dari hasil penelitian diperoleh gambaran bahwa indikator pengetahuan guru lebih dominan daripada indikator lain yang dijadikan ukuran dalam penelitian ini.

1. Secara empirik penerapan kompetensi pedagogik di SMK Negeri 11 Bandung, berada pada katagori baik. Hal ini ditunjukkan oleh skor rata-rata jawaban responden terhadap angket variabel kompetensi pedagogik, sebesar 4,03. Hal ini dapat diartikan bahwa persepsi responden terhadap kompetensi pedagogik dalam penelitian ini adalah siswa di SMK Negeri 11 Bandung mempersepsikan bahwa kompetensi pedagogik yang dimiliki guru sudah baik. Baiknya kompetensi pedagogik ini, berdasarkan hasil temuan penulis dilapangan, yang terlihatnya komunikasi dua arah yang terjadi dilapangan, sehingga dengan demikian komunikasi yang terjadi antara siswa dengan guru dapat berjalan dengan lancar.

2. Secara empirik sikap kewirausahaan siswa di SMK Negeri 11 Bandung berada pada kategori tinggi. Hal ini ditunjukkan oleh skor rata-rata jawaban responden terhadap angket variabel sikap kewirausahaan siswa, sebesar 3,95. Hal ini dapat diartikan bahwa persepsi responden terhadap sikap kewirausahaan dalam penelitian ini adalah siswa mempersepsikan bahwa sikap kewirausahaan yang dihasilkan siswa di SMK Negeri 11 Bandung sudah tinggi atau baik. Gambaran sikap kewirausahaan siswa di SMK Negeri 11 Bandung yang ditunjukkan oleh penelitian bahwa sikap kewirausahaan siswa yang sudah termasuk pada kategori baik. Dari hasil penelitian diperoleh gambaran bahwa indikator pemahaman siswa lebih dominan daripada indikator lain yang dijadikan ukuran dalam penelitian ini.

3. Dari penelitian, ini diketahui hasil bahwa adanya pengaruh antara kompetensi pedagogik guru terhadap sikap kewirausahaan siswa pada mata pelajaran kewirausahaan di SMK Negeri 11 Bandung. Sebagaimana variabel kompetensi pedagogik yang dominan ialah indikator kompetensi melaksanakan proses belajar dan mengajar dan sikap kewirausahaan yang dominan ialah indikator kepercayaan diri. Secara empirik dari hasil penelitian ini menindikasikan bahwa semakin tinggi kompetensi pedagogik yang dimiliki guru, akan diikuti oleh semakin tingginya sikap kewirausahaan siswa. Hal ini dapat diterangkan oleh persamaan regresi 
$\hat{Y}=1.54+1.63 X$. Dengan persamaan regresi tersebut dapat diinterprestasikan bahwa jika kompetensi pedagogik guru $(\mathrm{X})$ sikap kewirausahaan siswa $(\mathrm{Y})$ diukur dengan instrumen yang dikembangkan dalam penelitian ini, maka setiap perubahan skor kompetensi pedagogik sebesar satu satuan dapat diestimasikan skor tingkat sikap kewirausahaan siswa akan berubah sebesar 0, 393X satuan pada arah yang sama.

Berdasarkan kesimpulan dan pembahasan pada uraian sebelumnya maka saran yang dapat diusulkan penulis adalah sebagai berikut:

1. Dari hasil penelitian yang telah dilakukan, diperoleh gambaran bahwa kompetensi pedagogik di SMK Negeri 11 Bandung sudah hampir sama setingkat dengan efektif dan termasuk pada kategori baik, walaupun belum mencapai tingkat ideal. Merujuk pada hasil perhitungan pada uraian sebelumnya, pada variabel kompetensi pedagogik, indikator kompetensi melaksanakan penilaian proses belajar mengajar memiliki skor rata-rata terendah. Upaya yang dapat dilakukan untuk mengatasi masalah tersebut salah satunya adalah harus diadakannya suatu evaluasi yang baik dari guru terhadap siswa, bagaimana menciptakan penilaian yg baik agr siswa pun dapat memperbaiki kesalahan - kesalahan yang selama ini dilakukan.

2. Tidak jauh halnya dengan sikap kewirausahaan di SMK Negeri 11 Bandung yang dinilai tinggi, walapun belum mencapai ideal. Merujuk pada hasil perhitungan pada uraian sebelumnya, pada variabel sikap kewirausahaan, indikator berorientasi pada tugas dan hasil memiliki skor rata-rata terendah. Upaya yang dapat dilakukan untuk mengatasi masalah tersebut salah satunya dengan memberikan pelatihan kepada siswa yang belum mampu membuat suatu perencanaan, ataupun melaksanakan tugasnya dengan baik agar mendapatkan hasil yang lebih baik dan sesuai dengan yan diharapkan.

3. Penguasaan kompetensi pedagogik memiliki pengaruh yang cukup kuat terhadap peningkatan sikap kewirausahaan siswa. Sehingga penguasaan kompetensi pedagogik dapat secara signifikan mempengaruhi peningkatan sikap kewirausahaan siswa. Oleh karena itu, penuasaan kompetensi pedagogic guru yang baik akan secara signifikan berpengaru dan membantu peningkatan sikap kewirausahaan siswa secara langsung.

\section{Daftar Pustaka}

Alma, Buchari. (2002). Kewirausahaan. Bandung: Alfabeta.

Arikunto, S. (2002), Prosedur Penelitian Suatu Pendekatan Praktek Edisi Revisi V. Jakarta: Rineka Cipta..

Djamarah. (2002). Psikologi Belajar. Jakarta: Rineka Cipta.

Gomes, Faustino Cardoso. (2003). Manajemen Sumber Daya Manusia. Yogyakarta: Andi.

Hasibuan dan Moedjiono. (2006). Proses Belajar Mengajar. Bandung: PT. remaja Rosdakarya.

Iman Firmansyah dan Yoeningsih. (2009). Kewirausahaan Sekolah Menengah Kejuruan (SMK) Kelas XI. Bandung: HUP

Iman Firmansyah. (2009). Kewirausahaan Sekolah Menengah Kejuruan (SMK) Kelas XII. 
Bandung: HUP

Kasmir.(2007). Kewirausahaan. Jakarta: PT. Raja Grafindo Persada

Majid, Abdul. (2005). Perencanaan Pembelajaran : Mengembangkan Standar Kompetensi Guru. Bandung: PT. Remaja Rosdakarya.

Mangkunegara, AA Anwar. (2002). Manajemen Sumber Daya Manusia Perusahaan. Bandung: PT. Remaja Rosdakarya.

Mulyasa, E. (2007). Standar Kompetensi dan Sertifikasi Guru. Bandung: PT Remaja Rosdakarya.

Nasution. (2009). Berbagai Pendekatan dalam Proses Belajar dan Mengajar. Bandung: Bumi Aksara.

Oemar, malik. (2002). Proses Belajar Mengajar. Jakarta: PT. Bumu Aksara.

Sagala, Syaiful. (2009). Kemampuan Profesional Guru dan Tenaga Kependidikan. Bandung: Alfabeta.

Smith, Mark K dkk. (2009). Teori Pembelajaran dan Pengajaran. Yogyakarta: Mirza Media Pustaka.

Soemanto, Wasty. (1992). Sekuncup Ide Operasional Pendidikan Wiraswasta. Jakarta: PT. Bumi Aksara.

Somantri, Ating. Sambas Ali muhidin. (2006). Aplikasi Statistika dalam Penelitian. Bandung : Pustaka Setia.

Sugiyono. (2008). Metode Penelitian Administrasi. Bandung,: Alfabeta.

Suherman, Uman. (2002) Psikologi Pendidikan. Bandung: UPI Bandung.

Supardi, Endang (2004), Kiat Mengembangkan Kreativitas dan Innovasi, Modul Kewirausahaan, Dekdibud.

Suryana. (2006).Kewirausahaan Pedoman Praktis, Kiat dan Proses Menuju Sukses. Tidak Diterbitkan. Jakarta: Salemba Empat. 